FINAL PROGRESS REPORT

\title{
A Modular Program for Risk Assessment Education and Empowerment for Publics Surrounding Hazardous and Radioactive Waste Sites
}

\author{
Phoenix Environmental Corporation \\ June 17, 1998
}

\author{
Grant Number:
}

DE-FG01-95EW55086

\section{Grant Period:}

$3 / 17 / 95$ through $9 / 17 / 97$

\section{Current Status:}

The Stakeholder Toolbox and Risk Resource (STARR)document is in final draft form awaiting graphic layout and final technical reviews. Because grant monies were exhausted, these final activities are being conducting by Phoenix Environmental on a time-available basis. If additional funding is obtained, this work will proceed at a faster pace.

Accomplishments and Products Developed During the Grant Period:

- A great deal of research was done to identify available resources in print and on the world wide web. A bibliography and web site locator were developed.

- Numerous approaches were taken to condense and synthesize vast amounts of information before arriving at an approach that is best suited to stakeholder needs.

- The STARR document is in final draft form, requiring only final technical review and graphic design. The draft document was delivered to the DOE Risk Office.

- A half-day course on risk communication was developed and delivered at a DOE sponsored conference to positive audience reviews. This course remains available to the federal government.

- Phoenix Environmental participated in dozens of events and developed number technical papers to present preliminary results of the work and worked with many peer groups to evaluate and identify approaches to the document.

- Phoenix Environmental participated in numerous meetings of the other DOE risk grantees. 
The delays in finishing the STARR document are a result of a number of factors:

- The development of a document with the breadth and depth of STARR at a level that is useful to laypersons proved to be a much larger and more timeconsuming task than originally anticipated.

- A great deal of time and effort was spent to identify and establish a citizens advisory board for the effort, however, a functional group was never able to be established. Too many site-specific commitments on the part of stakeholders resulted in lack of available time to assist this effort.

- Considerable effort was put into a commensurate training course which was delivered at one DOE event but not repeated. That course received very positive reviews and remains available for use by the Federal government.

- Lack of resources by the grantee to continue this effort without outside support has made progress since the end of the award period slow.

\section{Completion Schedule:}

Phoenix Environmental continues to work on the STARR document and hopes to have a completed document within fiscal year 1999. 


\section{DISCLAIMER}

This report was prepared as an account of work sponsored by an agency of the United States Government. Neither the United States Government nor any agency thereof, nor any of their employees, make any warranty, express or implied, or assumes any legal liability or responsibility for the accuracy, completeness, or usefulness of any information, apparatus, product, or process disclosed, or represents that its use would not infringe privately owned rights. Reference herein to any specific commercial product, process, or service by trade name, trademark, manufacturer, or otherwise does not necessarily constitute or imply its endorsement, recommendation, or favoring by the United States Government or any agency thereof. The views and opinions of authors expressed herein do not necessarily state or reflect those of the United States Government or any agency thereof. 


\section{DISCLAIMER}

Portions of this document may be illegible in electronic image products. Images are produced from the best available original document. 